\title{
An Exploration of the Drivers of Employee Motivation to Facilitate Value Co-creation
}

Donia Waseem is a Lecturer in Marketing at the University of Bradford. Her work has been published in Industrial Marketing Management.

Sergio Biggemann is a Senior Lecturer at the University of Otago. His work has previously been published in various academic journals such as Journal of Business Research, Industrial Marketing Management, and Journal of Business \& Industrial Marketing etc.

Tony Garry is an Associate Professor at the University of Otago. His work has previously been published in various academic journals such as Industrial Marketing Management, Journal of Service Management, Journal of Marketing Management, Journal of Services Marketing, and Journal of Brand Management etc. 


\section{An Exploration of the Drivers of Employee Motivation to Facilitate Value Co-creation}

Purpose - This study provides empirically based insights into the motivations of employees to facilitate value co-creation. In doing so, it enhances our understanding of the social and contextual elements that contribute towards the co-creation of value.

Methodology - This research draws on 57 in-depth interviews together with participant observation field notes. Data were examined using thematic analysis.

Findings - We identify six key drivers that motivate employees to facilitate value co-creation: rewards and recognition, opportunities for life-long learning, interpersonal engagement, role responsibility and accountability, organisational vision, and social purpose.

Originality/value - Drawing on service-dominant logic (S-D logic) as a theoretical lens, this study adopts and adapts Lindenberg and Steg's (2013) goal-framing theory to conceptualize six drivers of employee motivation to facilitate value co-creation within three-goal frames that leads to inrole and extra-role job performance.

Research limitations/implications - This study is undertaken within a traditional organisational setting. Other organisational contexts such as home working should also be considered.

Keywords: Service dominant logic, value co-creation, employee motivation, goal-frames

Article Type: Research paper 


\section{Introduction}

Viewed through the lens of service-dominant (S-D) logic, value co-creation is a multi-stakeholder phenomenon involving multiple actors benefitting one another (Kleinaltenkamp et al., 2012; Storbacka, Brodie, Böhmann, Maglio, \& Nenonen, 2016). As such, value co-creation may be interpreted as occurring between actors within social situations and has hence been labelled valuein-social-context (Edvardsson, Tronvoll, \& Gruber, 2011). Within the service marketing literature (e.g., Boukis, Gounaris, \& Lings, 2017), the strategic importance of employees as actors in cocreating value for organisations has long been recognised (Bitner, 1992; Grönroos, 1999). The initiation of value co-creation processes within many firms is frequently attributable to employee actions. As such, there is an increasing focus on how such actions may be encouraged (Ramaswamy, 2009). For example, Indian multinational vehicle manufacturers Mahindra and Mahindra attempted to implement a culture of co-creation through transformational change within the organisation by focusing on developing employee resource capability and through co-creation platforms. To achieve this goal, experienced employees volunteered to share knowledge and expertise delivering 50 specialized workshops to over 500 employees without any additional cost to the firm (Randall, Ramaswamy, \& Chopra, 2014). Crucial to the success of this exercise was the level of participation and the accompanying engagement of employees (Van Doorn et al., 2010).

Previous research has explored employee roles within several value co-creation contexts including leadership (Hsiao, Lee, \& Chen, 2015), frontline service employees (Santos-Vijande, López-Sánchez, \& Rudd, 2016; Van der Heijden, Schepers, Nijssen, \& Ordanini, 2013), and healthcare professionals (Hardyman, Daunt, \& Kitchener, 2015). A common assumption with all these studies is that value co-creation results from the motivations of individual actors (cf. 
(Findsrud, Tronvoll, \& Edvardsson, 2018; Van Doorn et al., 2010). Previous research has explored the motivational drivers of customers in the value co-creation process (Roberts, Hughes, and Kertbo (2014), a unifying theoretical frame of reference that explicates the motives that could lead to maximizing value for all beneficiaries is missing.

Value is widely recognized as being phenomenologically determined by individual actors and influenced by the social contexts within which such value is co-created (Edvardsson et al., 2011). To expand our understanding of value co-creation processes, it is therefore important to examine the different social contexts that influence actors, including employees, to participate in or facilitate the co-creation of value (Chandler \& Lusch, 2015; Chandler \& Vargo, 2011). However, research that focuses specifically on the motivations of employees' to facilitate value co-creation processes is largely overlooked within the literature. Consequently, this study aims to address this gap by providing empirically generated insights into the motivations of employees to participate in and facilitate value co-creation. By doing so, a more balanced approach to theory building is adopted (Gummesson, 2008). To this end, the contribution of this research is twofold. From a theoretical perspective, it contributes to the SDL literature by offering a conceptual framework encompassing six drivers of motivation that lead to in-role and extra-role job performance that facilitate value co-creation. From a pragmatic perspective, the conceptual model derived from the findings of this research may aid practitioners in developing a more robust focus on the drivers of employee motivation that enhance extra-role performance and incentivize these as appropriate.

The paper is structured as follows. First, we explain the concept of value co-creation within social contexts and how these may relate to drivers of motivation. Next, the research methodology is outlined followed by the findings section in which six key drivers of employee motivation are 
presented. In the discussion section, we adopt and adapt Lindenberg and Steg's (2013) goalframing theory to explore how these motivators may result in extra and in-role job performance that potentially facilitates value co-creation. Finally, conclusions are drawn and directions for future research suggested.

\section{Theoretical Background}

\section{Value co-creation}

Service-dominant logic (S-D logic) views value co-creation as a process where multiple actors benefit one another (Kleinaltenkamp et al., 2012; Storbacka et al., 2016). As such, value cocreation becomes a multi-actor phenomenon (Kleinaltenkamp, Plewa, Gudergan, Karpen, \& Chen, 2017; Vargo, Lusch, \& Akaka, 2010) with actors embedded within complex social systems (Edvardsson et al., 2011) potentially involving many different levels of interaction and value creation. These levels may encompass the micro (such as an individual's disposition and engagement properties), meso (such as actors and resources, engagement platforms, and resource integration patterns), and macro (such as institutional logic and service ecosystem) (Beirão, Patrício, \& Fisk, 2017; Storbacka et al., 2016). Implicit within this is that individuals experience value co-creation from various social perspectives, levels and contexts (Chandler \& Vargo, 2011). Consequently, social forces (such as job positions and roles) and contextual elements (such as norms, values, culture, etc.) play a significant role in value co-creation processes (Malthouse \& Calder, 2011). Extant literature in this arena has tended to focus on limited perspectives (e.g., customers) and macro-level social contexts (e.g., firms) and in doing so constrain a more balanced foundation for theoretical development (Gummesson, 2008). Indeed, Felin and Hesterly (2007) challenge conventional macro or firm-level capabilities and knowledge-based approaches 
proposing instead that the locus of value creation lies at the micro or individual level. Their argument focuses on the premise that organisations are made up of employees and that organisations cannot create value effectively without employees (Baron \& Kreps, 1999).

At the micro-level, several studies have examined the role of employees on value cocreation process outcomes and entities. Specifically, Hsiao et al. (2015) identify how firm leadership can systematically stimulate customer value co-creation. Merrilees, Miller, and Yakimova (2017) examine staff engagement as a facilitator of employee-led value co-creation identifying how practices such as the proactive helping of clients and service innovation may facilitate value co-creation. Santos-Vijande et al. (2016) examine how frontline service employees' collaborative practices influence service development. Boukis and Gounaris (2014) examine the relationship between internal marketing orientation (IMO) and service employees' positive behavioural outcomes, identifying how IMO can raise perceived employee to fit with their organisation and managers. Similarly, Van der Heijden et al. (2013) explore the conditions under which frontline service employees engage in additional roles suggesting that employee knowledge sourcing may trigger employees to develop ideas which may positively influence the innovation development process. Extrapolating this further, Plé (2016) proposes that service employees engaged in co-creative innovative processes with customers may or may not integrate customers' resources resulting in co-creation or co-destruction. In a multi-stakeholder study, O'Cass and Sok (2013) examined the role of managers and employees in the creation and delivery of superior value to customers via the firm's innovation capability, concluding that service firm's innovation capability, firm's value offering, customer perceived value-in-use, and firm performance positively impact each other. Finally, Hardyman et al. (2015) explored micro-level practices such 
as the 'frontline' service interactions in health care service encounters which result in value cocreation.

In summary, whilst these studies examine issues related to micro-levels of value cocreation that encompass employee leadership, employee engagement, employee collaboration practices and employee development and innovation, none examine employee motivations that facilitate these value co-creation processes (cf. (cf. Van Doorn et al., 2010). In the next section, we explore employee motivation as a potential facilitator of co-creation focusing on goal framing theory.

\section{Employee motivations}

Motivation is a psychological process that directs and energizes an individual's inner desire to take action (Grant \& Shin, 2012; Latham \& Pinder, 2005). It is a set of process-orientated forces (Pinder, 1998) that drive an individual to apply resources that result in multi-dimensional streams of behaviours (Kanfer, 1990; Mitchell, 1982). Disciplinary fields as diverse as psychology (e.g., Grant \& Shin, 2012), management (e.g., Latham \& Pinder, 2005; Locke \& Latham, 2004), education (e.g., Dörnyei \& Ushioda, 2013), and organisational behaviour (e.g., Katz, 1964) have long recognized the importance of motivation in influencing behaviours and actions particularly within contexts where outcomes are dependent on interactions between multiple individuals.

Goal-framing theory integrates insights from social (cognitive) psychological, and behavioural economics (Foss and Lindenberg, 2013) to offer a rich conceptual framework that may explicate an individual's motivation within an organisational context. It posits that three different goal frames, namely normative, hedonic, and gain goal, drive the motivations of individuals. Within normative goal framing, individuals act in the belief that it will be for the collective benefit of an entity. Within hedonic goal framing, individuals act to improve how they 
feel in the present. In gain goal framing, individuals act in an attempt to improve their resources (Foss \& Lindenberg, 2013; Lindenberg \& Foss, 2011). The form a goal is framed in results in two generic types of performance, in-role and extra-role performance. Employee in-role performances are the required fulfilment of a formal job description. Extra-role performance is the performance of an employee that goes beyond the formal requirements of the job (MacKenzie, Podsakoff, \& Fetter, 1991). As such, in-role performance is characterized by its variation between jobs whereas extra-role performance is generally similar across jobs (Sonnentag, Volmer, \& Spychala, 2008).

Viewing employee motivations through Lindenberg and Steg's (2013) goal-framing theory may contribute to our understanding of how individual motivations might be mobilized and sustained for value co-creation purposes and hence enable firms to strategically manage resources and interactions with employees. However, little attention has been paid to the drivers of employee's motivation that facilitate value co-creation. Hence, this research aims to provide insights into these drivers.

\section{Methodology}

Given the nature of the study, qualitative research was adopted embracing an interpretive paradigm that views reality as subjective and socially constructed (Saunders, Lewis, \& Thornhill, 2009) through experiences of actors (Sandberg, 2005). Ontologically, the study adopts a relativist stance which assumes that reality is constructed inter-subjectively. From an epistemological perspective, the study adopts a social stance insofar as reality may change its meanings when interpreted by different individuals and that such interpretations are developed experientially and socially (Mertens, 2015). In line with this view, Helkkula, Kelleher, and Pihlström (2012) suggest that value co-creation will reflect employees lived experiences extending beyond their current context 
and encompassing past and future experiences. Such an approach assumes that individuals build multiple subjective meanings of their experiences. In adopting such an approach, a researcher is exposed to complex insights and perceptions of employees when communicating their motivational drivers and behaviours (Creswell, 2014).

Fifty-seven interviews were conducted at a tile-manufacturing firm employing over 1,800 staff, (see Table I for details of the participants). Additionally, the principal researcher conducted 12 weeks of participant observations within different functions and levels of the organisation.

-Insert Table I here-

As the firm is a multi-site operation, in-depth interviews were conducted across three different locations. Interviews lasted between 18 and 90 minutes. All interviews were audiotaped and subsequently transcribed (verbatim). Participants did not restrict their experiences to their current tenure within the tile manufacturing firm but were encouraged to include experiences from their entire professional life. The principal researcher engaged with the participants in their natural setting which provided an emic perspective (Morey \& Luthans, 1984) without imposing the researcher's bias. This added depth to the understanding of the phenomenon under investigation.

In-depth observation of employees took place during working hours in the employees' respective departments. Observation times were dependent on the scope of the participant's work. For example, the sales function and its team members were observed for two weeks to ensure enhanced contextual understanding. Other functions of the firm such as human resource, 
marketing, finance, production, and logistics were also observed on average for one week per department. In participant observation, the participants and the researcher engage in social interaction. Such interaction enables the observation of participants in their natural setting (Taylor \& Bogdan, 1984), and consequently contribute towards a singular interpretation of their utterances. Participants were made fully aware of the nature of the research and the researcher's intentions. In turn, the researcher familiarized themselves with the role and routines of the department, the employees (both participant and non-participant), and was able to attend departmental meetings. Observation included visiting the firm's head office, two production plants (a wall and a floor tile manufacturing plant), the regional sales office, and an outlet (emporium) within a major city. The field notes that accompanied the observations resulted in 60 pages (32,500 approx. words) of text. Additionally, 69 photographs were taken of the ergonomics, products, and the surroundings of the firm. Whilst the main focus of data collection was on the lived experiences of participants captured via in-depth interviews, the observations assisted in framing participants' background, and workplace context. Hence, it assisted in deriving a holistic perspective of a participant's experience contributing to a richer explication of data.

Transcripts of interviews and field notes went through thematic analysis (Braun and Clarke, 2006), which involves becoming familiar with the data, open coding, grouping codes into themes, and an abstraction process to formulate the description of the themes. First, data were checked for accuracy. After making sense of and becoming familiar with the data, passages on value cocreation were identified (i.e., individuals' utterances that we construed as value co-creation). Coded data were rearranged under grouped codes until similar-meaning themes emerged. By arranging and rearranging themes, a framework emerged in which the whole description represented a cohesive narration as well as individual contexts (see Table II). 
-Insert Table II here-

To improve data validity (communicative) and reliability (interpretive awareness) Sandberg (2005) approach was adopted. Communicative validity was achieved (Kvale, 1995) through methodological triangulation (Patton, 1999). In-depth observation provided clearer insights into the meaning derived from participant interviews. Reliability as interpretive awareness (Sandberg, 2000, 2005) was achieved by asking several open-ended questions and then following these up with probes. We further strengthened interpretive awareness by contacting several participants to confirm interpretations of their data.

Data analysis encompassed an employee's relational self-concept (cf. (Brewer \& Gardner, 1996). Experiences relayed to the researcher were considered to be value co-creation if they encompassed relational experiences with other actors. More precisely, we define value co-creation as a multi-stakeholder phenomenon which involves multiple actors benefitting one another (Kleinaltenkamp et al., 2012; Storbacka et al., 2016) and it is interpreted as value-in-social-context (Edvardsson et al., 2011). This criterion was undertaken to identify co-creation experiences shared by employees and which benefited both the firm and other employees. These frequently involved both one-on-one and one-on-many interactions that encompassed multiple individuals in various roles such as other employees, dealers, suppliers etc. By doing this, a more holistic view of employees and their broader social contexts of value co-creation experiences was ensured. 


\section{Findings}

Six thematic categories that evoked motivations among employees to facilitate value co-creation were identified. These were labelled as follows: 1) rewards and recognition processes, 2) opportunities for life-long learning, 3) interpersonal engagement, 4) role responsibility and accountability measures, 5) organisational vision, and 6) social purpose.

Organizational processes that recognized and rewarded engagement in co-creation activities were identified as drivers of motivation. From an employee perspective, reward and recognition would manifest themselves through incentive systems, monetary benefits, promotion, access to particular facilities, and financial allowances. These also encompassed informal processes and non-monetary benefits such as outdoor activities, meals offsite, and other rewards perceived as increasing morale. For example, Participant N describes that "at worker (tactical work) level... if a manager or a GM [General Manager $]$ keeps his hand on his shoulder than he feels proud... that they're recognizing my work and they're appreciating so then the energy he puts in his work is 500 times more." Participant T outlines how the firm would conduct strategy meetings with employees off-site in premium hotels in an attempt to increase employee engagement and motivation with activities that involved value co-creation. Specifically, Participant T explained how he was tasked with establishing an additional shift in their manufacturing plant that would encompass significant cooperation between employees in co-creating the processes involved: "It was a single shift operation and demand was very high so the chairman said we will go for double shift operation."

He engaged with employees to jointly design the co-created activities relevant to the introduction of the new shift. Participant $\mathrm{T}$ describes how he felt this boosted employee morale whilst engaging them in an environment in which they felt valued and appreciated. He went onto share: "We called them into five-star and four-star hotels, and we conducted strategy meetings...full facilities, 
meals...we had to boost up their morale and we don't have to provide the knowledge. We took them to XYZ stadium, over there..... we took them and made them play football. It wasn't binding on anyone if someone wants to go home...they can. This way we build up their morale..." (Participant T).

These activities increased employee engagement and motivation to participate in the planning and establishment of the additional shift. Additionally, there was a collective sense of empowerment and ownership among employees. A common theme to emerge from these findings was that activities that were perceived as being co-creative in nature, were frequently considered by employees as directly benefiting them. This insight aligns with the gain goal frame where an individual is motivated to improve his or her resources (Foss, 2011; Lindenberg \& Foss, 2011).

Participant $P$, an auditing manager, shared his experience (whilst with a previous employer) where he was tasked with conducting a bank audit. He described that under normal circumstances, the size of the team assigned to that task would comprise approximately 26 trainee-chartered accountants. However, he was only given a team of 11 individuals as the other trainees were engaged in a different project. To get the work of 26 individuals done by 11 individuals, the team had to significantly increase their productivity and work extra hours. To achieve the desired outcome, activities were collectively designed amongst the team in a way that was perceived as enhancing resources whilst leveraging financial incentives and non-financial benefits for the employees. The auditing manager ensured the co-creation of auditing processes through the integration of his team's knowledge and skills in such a way that the overall project was both costeffective and beneficial to the organisation. A trainee accountant's starting salary is relatively low, and they were motivated to engage in the auditing process through rewards such as travelling and food allowance. Participant P elaborated: "The team had a lot of input in it. The team I've got was 
very supportive and the people were cooperative. So, I used to motivate them like... tell me what will you eat today? So, this was the way things were done." This example illustrates how recognising employees' increased operant resource contribution (Foss, 2011; Lindenberg \& Foss, 2011) through rewards enhances their motivation to facilitate value co-creation processes (Vargo \& Lusch, 2017).

Another driver of employee motivation to facilitate value co-creation was identified as organizational processes that provide opportunities for life-long learning. These were perceived as offering employees the opportunity to acquire and share knowledge and experience and hence develop operant resources (Vargo and Lusch, 2016). Platforms that offered such opportunities included conference attendance, training courses, work-based experimentation and innovation, and the encouragement of risk-taking in decision making. Such activities and experiences were frequently co-created through interaction with other employees (Foss, 2011; Lindenberg \& Foss, 2011). For example, Participant R, a production manager, shared his experience of developing an additional production unit within a car manufacturing firm in a previous role. He explained how the firm trained employees and equipped them to carry out highly specialized technical tasks related to the manufacturing processes. Given stringent safety requirements inherent within the finished product, even small procedures (e.g., tightening bolts) were required to be meticulously documented as part of the firm's standard operating procedures. The firm was required to hire a tranche of new employees who were inexperienced and unskilled in the technical elements of the operational processes. As such, significant investment in training was required to enable the new employees to understand and follow the correct procedures to the required safety specifications. This learning opportunity upskilled employees and enhanced their knowledge of a specialized but key technical area within car manufacturing. Participant R explained: “...their training was good, 
and their level of knowledge is good, and they now know how to do the job well." He outlined how employees were collectively encouraged to participate in new process development and actively adopted an experimental approach during the designing process.

These collaborative learning activities enhanced training whilst encouraging a participative environment that facilitated employee team building. In this way, learning opportunities which motivated employees were embedded in the co-creation activities involved in the work design processes within the new unit. Drivers of motivation to co-create value through input into work design practices (Patrício, Gustafsson, \& Fisk, 2018) were driven by learning opportunities that ultimately lead to enhanced operant resources. This is reflective of the gain goal framing orientation (Foss, 2011; Lindenberg \& Foss, 2011).

Examples of relational drivers of employee motivation to facilitate value co-creation are interpersonal engagement processes such as direct interaction and perceived equitable treatment. Value co-creation through interpersonal interaction manifested itself through encouragement, collaborative engagement, empowerment, mutual trust, cooperation, exhibiting confidence in each other's abilities, commitment, and collective understanding. A common theme that emerged within these findings was the positive affect evoked among employees by constructive and direct interpersonal interactions. For example, Participant $X$, a managing director, articulated the impact of frequent and direct interaction with employees. Specific examples included time chatting to production workers on the shop floor and having morning tea at the office canteen. At a personal level, he felt he was more approachable and connected with his employees. Through this process, he was able to acquire knowledge, often tacit, about the specifics of particular employee jobs and hence, increase his operational knowledge of the manufacturing plant overall. Participant $\mathrm{X}$ explained: "Whenever I walked into the factory I used to spend a lot of time in the factory walking 
around. You see these workers; they'd grab my hand and take me to the canteen, and they'd say please have tea with us. I'd spend a lot of time in the canteen with the workers, chit-chatting, having tea and biscuits with them.... and seeing the machines being operated. They felt I was a part of them, there was no management and workers." He further explained: "They were the people who would deliver results..." In this way, the employee value co-creation experience was interpersonal connectivity, information exchange, encouragement and collaboration with other employees. Such shared experiences and interpersonal engagement processes are consistent with the literature on engagement and motivation (Fernandes \& Remelhe, 2016; Roberts et al., 2014). These findings are also reflective of hedonic goal framing where the self is motivated towards improving how he or she feels through connectivity (Foss, 2011; Lindenberg \& Foss, 2011).

Another driver that motivates employees to engage in facilitating co-creation activities is the role of responsibility and accountability measures. If an employee felt responsible for performing a certain activity, they felt accountable for its completion. However, from a co-creation perspective, it was the process involved in establishing responsibility and accountability that was frequently perceived as creating value. Examples of these included negotiating in-role responsibility, agreeing on areas of accountability, and holding other employees to account. Participant G explains how a c-suite executive co-created value by developing accountability measures with employees: “...instead of asking the plant manager or the GM (general manager), he would ask the guy directly responsible [on the shop floor] to get involved". Hence, accountability measures held individuals responsible for their tasks and increased the motivation of these individuals to engage in these activities.

Participant $\mathrm{F}$ explained how he felt a personal responsibility to fulfil his role within the accounts receivable department. One such task was to process discounted invoices. The firm's 
policy was that regional or zonal sales managers (ZSM) should not approve transactions beyond pre-determined discount limits but were allowed to exceed these amounts in exceptional circumstances such as to secure a major deal. Whilst this would not generate additional profit for the firm because of the discounted amounts, it could potentially allow the fulfilment of a zone's sales target. However, this became an issue as the achievement of the sales target was increasingly being viewed as a priority over profit by zonal sales manages. Participant F was able to identify higher than authorized discounts by personally developing a process to cross-check invoices with daily transactions and identify discrepancies. Subsequently, he would work with ZSMs to educate them about the impact of their decisions and to identify potential solutions. Participant F stated: "For me, work is to run my department adequately. At times I had to sit to 11:00 pm to do the work... You know that there's a lot of workload. Work is pretty much the same. I have an option, I'm doing my work... But I have a responsibility and if something is coming into my hands then I'm responsible." In this way, the employee was motivated from a sense of responsibility to cocreate the firm's sales policy with the ZSMs. Such a normative goal frame stems from a sense of responsibility and accountability whereby an individual is motivated towards action to benefit the collective goal (Foss, 2011; Lindenberg \& Foss, 2011).

Another driver that motivates employees to engage in value co-creation processes is shared organisational vision. These visions were communicated formally such as through internal presentations and monthly or quarterly meetings. They were further strengthened by informal interactions such as through engagement with and adoption of the vision at a personal level. Within this context, employees frequently reflected on the organisational vision and how they could implement activities that reflected it and/or contributed to its achievement. Participant A explained when he joined the firm he attempted to engage and motivate employees by developing a shared 
vision for the future with them. He outlined how a key challenge was the 'silo mentality' of the organisation manifesting itself in each department following their agenda frequently to the overall detriment of the firm. He instigated a strategic planning committee that consisted of all the departmental heads to develop and take collective ownership of the vision. Participant A elaborated: "The team [i.e., the department heads] was not in gel with what a vision of the company was. So, the first thing...... I tried to do, and I think I was successful in doing was... have a shared vision of the company with the team so that was an important exercise." There was an expectation that department heads would champion and engage employees with the collective vision at a departmental level. This was a key driver in facilitating employee engagement and motivation as departmental heads would go beyond their job role to co-create value with employees and for the organisation. Whilst these findings are vision is consistent with the service literature on value cocreation (e.g., (Kruger, Caiado, França, \& Quelhas, 2018; Zhao, Wang, \& Fan, 2015), they are also reflective of a normative goal framing orientation insofar as employees are motivated to cocreate value to achieve a collective vision be it at an organisational or departmental level.

The final theme focuses on the notion of socially conscious business and its contribution to a social purpose. The social purpose was perceived as extending beyond the firm's boundaries and encompassing the welfare of the wider community, and society at large. Several respondents recounted how they frequently envisioned themselves as contributing to this higher purpose through their daily activities. Participant B described how the Chairman had communicated such a higher organisational purpose and its contribution to the greater good of society. Consequently, Participant B was motivated to go the 'extra mile' to create value collectively with his fellow employees in the belief that they were contributing to this greater good. Participant B explained, "Apart from the monetary benefits, facilities etc. what tied me to that company was [that] the 
CEO's goal was to earn money [profit for the company] and invest in the country's social development sector. The motivation and appreciation are there but when you're working for a higher purpose and a collective goal for a broader picture and the [greater] betterment then you're tied down to the company. " In this way, the social purpose of the organisation was a key driver of employee motivation to co-create value through their work. These findings support Gillespie and Mann (2004) research which emphasizes the importance and alignment of shared purpose to perform 'above and beyond' expectations at work (Waseem, Biggemann, \& Garry, 2018).

\section{Discussion and conclusion}

This research explored the drivers of employee motivations that facilitate value co-creation. In discussing the findings, we further adopt and adapt Lindenberg and Steg's (2013) goal-framing theory to explain these key motivations. Our findings identify six drivers, which we categorize into the three types of goal frames namely: gain, hedonic, and normative. These three-goal frames result in two types of performance: a) in-role and b) extra-role job performance that motivate employees to facilitate value co-creation. See Figure 1.

-Insert figure 1 here-

Employee motivational drivers that facilitate value co-creation are influenced by organisational processes that are perceived as contributing to or developing personal resources and that enable their application. Within a gain goal frame, individuals attempt to increase and improve 
their resources to enhance in-role performance (Foss \& Lindenberg, 2013; Lindenberg \& Foss, 2011). Viewed through an SDL lens, rewards, recognition and training not only enable and recognise the fulfilment of employee in-role performance but develop their operand and/or operant resource base which may subsequently be applied to facilitate value co-creation with other employees. Organisations should identify and develop processes that encompass activities that offer the opportunity for employees to develop their operant and operand resources and that recognise the application of these by employees to co-create value. Such processes may include employee recognition schemes, educational and training opportunities, career planning and other opportunities for lifelong learning. This approach also resonates with Vargo and Lusch (2017) insofar as the application of operant and operand resources are geared towards collective efforts at improving firm efficiency and profitability. However, to facilitate this may require an evaluation of current in-work design to ensure there are opportunities to engage with and co-create value with other employees at a cross-functional level (Grant, 2007).

Our findings also identify how interpersonal engagement drives motivation to facilitate value co-creation. Within hedonic goal framing, individuals are motivated to act to improve how they 'feel' in the present moment (Foss, 2011; Lindenberg \& Foss, 2011). The nature of interaction with colleagues frequently evoked positive emotions that, taken collectively, created an environment conducive to achieving positive outcomes (Edvardsson et al., 2011). The characteristics of these interactions included connectedness, collaboration, engagement, empowerment, trust, confidence, support, and interdependence. These were perceived as forming an over-arching social setting that motivated employees and facilitated value co-creation between them. Such interactions also influenced perceptions of equality among employees and in doing so transformed the nature of organizational relationships from one of a traditional hierarchical 
framework to one of a more informal and collaborative relationship (Chen et al., 2020; Sluss and Ashforth, 2007). Hence, our findings suggest creating environments of mutual understanding, appreciation, and cooperation within interpersonal processes facilitate value co-creation. Consistent with (Jaakkola \& Alexander, 2014) findings, work-related social contexts are an essential driver of value co-creation. Such contexts, and the relational processes that take place within them, are an important source of sustaining value co-creation for the long-term benefits of the involved stakeholder (Vargo \& Lusch, 2016).

Our findings identify organizational vision, social purpose, role responsibility and accountability as drivers of employee motivation that facilitate value co-creation and provide insights into how these can be leveraged to further enhance co-creation (FitzPatrick, Varey, Grönroos, and Davey (2015). These drivers are perceived by employees as facilitating co-creation of value that contributes towards the specific achievement of collective goals. Hence, we suggest these are framed by employees as normative goals (Foss and Lindenberg, 2013). The collective nature of these goals frequently means employees are prepared to go 'above and beyond' in their anticipated level of achievement. Extra-role performances refer to the actions of employees that are not required as part of their formal job role but are still directed towards achieving organisational goals. Because of its nature, extra-role performance may evoke increased affective commitment to the organization leading to positive organizational-level outcomes such as increased profitability, productivity, and cost efficiencies (Podsakoff, Whiting, Podsakoff, and Blume (2009).

Our findings support Gillespie and Mann (2004) research which identifies the importance of shared purpose and vision in aligning employee actions achieving shared goals. Reflective of Vargo and Lusch (2017), we posit that organisational processes should be designed to enable 
employees' to leverage their operant and operand resources to achieve collective goals with a wider range of both internal and external stakeholders (Boukis and Kabadayi (2020).

\section{Conclusions}

Using S-D logic, this research examined an under-explored stakeholder in the value co-creation process i.e., employees, thereby responding to a call by Gummesson (2008), to contribute to a more balanced theoretical foundation for value co-creation. In doing so, we adopted and adapted Lindenberg and Steg's (2013) goal-framing theory to conceptualize six key drivers of employee motivation in three-goal frames that lead to in-role and extra-role job performance that facilitate value co-creation. A clear understanding of the drivers of motivation is essential to effectively optimise in-role and extra-role performances that lead to enhanced value co-creation (Lindenberg \& Foss, 2011). In doing so, this study extends our understanding of S-D logic and the significance of contextual social forces that influence value co-creation.

\section{Practical implications, limitation, and areas for future research}

Motivated employees are a key source of strategic benefit to an organisation. Determining the drivers of motivation enables firms to identify how they may be framed in terms of goals to enhance both the in-role performance and extra-role performance of employees and hence optimise value co-creation (Lindenberg \& Foss, 2011). In particular, strategic efforts should attempt to enhance the drivers that create a normative goal framing orientation as this would enhance the extra-role job performance of employees. Reframing organisational processes in ways that recognise and complement extra-role behaviours ensures normative goals remain at the forefront of the organisation. These may be related to the characteristics of the firm and its culture and the factors that influence these. Human Resource policies should recognise the significance of leadership style and how these relate to informal recognition and rewards at the shop floor level. 
Empowerment and resourcing of supervisors to initiate team building activities that contribute towards an esprit de corp among employees may be appropriate. Additionally, consideration should be given to employee appraisal schemes that encompass the identification of employee aspirations for self and collective improvement. This may focus on ensuring employees are equipped with the necessary operant and operand resources to maximise value co-creation processes. Given their collective nature, these key drivers may strategically influence other stakeholders such as customers, suppliers and buyers as they are also beneficiaries of any value co-created.

This study is undertaken in a traditional organisational setting so there is an opportunity to explore the drivers of motivation that facilitate co-creation within different working contexts. For example, there are contexts where tasks are interdependent but individuals are geographically separate e.g., virtual teams (Hertel, Konradt, \& Orlikowski, 2004; Sluss \& Ashforth, 2007) or working from home scenarios. Secondly, this study focused on the individual relational orientations of employees. There is an opportunity to explore the collective orientation of employees. This would be an interesting direction to take further research. 


\section{References}

Baron, J. N., \& Kreps, D. M. (1999). Strategic human resources: Frameworks for general managers. New York: John Wiley \& Sons.

Beirão, G., Patrício, L., \& Fisk, R. P. (2017). Value cocreation in service ecosystems. Journal of Service Management, 28(2), 227-249.

Bitner, M. J. (1992). Servicescapes: The impact of physical surroundings on customers and employees. Journal of Marketing, 56(2), 57-71.

Boukis, A., \& Gounaris, S. (2014). Linking IMO with employees' fit with their environment and reciprocal behaviours towards the firm. Journal of Services Marketing, 28(1), 10-21.

Boukis, A., Gounaris, S., \& Lings, I. (2017). Internal market orientation determinants of employee brand enactment. Journal of Services Marketing, 31(7), 690-703.

Boukis, A., \& Kabadayi, S. (2020). A classification of resources for employee-based value creation and a future research agenda. European Management Journal. doi:https://doi.org/10.1016/j.emj.2020.05.001

Brewer, M. B., \& Gardner, W. (1996). Who is this" We"? Levels of collective identity and self representations. Journal of personality and social psychology, 71(1), 83-93.

Chandler, J. D., \& Lusch, R. F. (2015). Service systems: a broadened framework and research agenda on value propositions, engagement, and service experience. Journal of Service Research, 18(1), 6-22.

Chandler, J. D., \& Vargo, S. L. (2011). Contextualization and value-in-context: How context frames exchange. Marketing Theory, 11(1), 35-49.

Creswell, J. W. (2014). Research design: Qualitative, quantitative, and mixed methods approaches (4 ed.). Thousand Oak, CA: Sage Publications. 
Dörnyei, Z., \& Ushioda, E. (Eds.). (2013). Teaching and researching: Motivation (2 ed.). Harlow: Longman.

Edvardsson, B., Tronvoll, B., \& Gruber, T. (2011). Expanding understanding of service exchange and value co-creation: a social construction approach. Journal of the Academy of Marketing Science, 39(2), 327-339.

Felin, T., \& Hesterly, W. S. (2007). The knowledge-based view, nested heterogeneity, and new value creation: Philosophical considerations on the locus of knowledge. Academy of management Review, 32(1), 195-218.

Fernandes, T., \& Remelhe, P. (2016). How to engage customers in co-creation: customers' motivations for collaborative innovation. Journal of Strategic Marketing, 24(3-4), 311326.

Findsrud, R., Tronvoll, B., \& Edvardsson, B. (2018). Motivation: The missing driver for theorizing about resource integration. Marketing Theory, 18(4), 493-519.

FitzPatrick, M., Varey, R. J., Grönroos, C., \& Davey, J. (2015). Relationality in the service logic of value creation. Journal of Services Marketing, 29(6/7), 463-471.

Foss, N. J. (2011). Invited editorial: Why micro-foundations for resource-based theory are needed and what they may look like. Journal of management, 37(5), 1413-1428.

Foss, N. J., \& Lindenberg, S. (2013). Microfoundations for Strategy: A Goal-Framing Perspective on the Drivers of Value Creation. Academy of Management Perspectives, 27(2), 85-102.

Gillespie, N. A., \& Mann, L. (2004). Transformational leadership and shared values: The building blocks of trust. Journal of managerial psychology, 19(6), 588-607.

Grant, A. M. (2007). Relational job design and the motivation to make a prosocial difference. Academy of management Review, 32(2), 393-417. 
Grant, A. M., \& Shin, J. (2012). Work Motivation: Directing, Energizing, and Maintaining Effort (and Research). In R. M. Ryan (Ed.), Oxford Handbook of Motivation (pp. 505-519). Oxford: Oxford University Press.

Grönroos, C. (1999). Relationship marketing: challenges for the organization. Journal of Business Research, 46(3), 327-335.

Gummesson, E. (2008). Extending the service-dominant logic: from customer centricity to balanced centricity. Journal of the Academy of Marketing Science, 36(1), 15-17.

Hardyman, W., Daunt, K. L., \& Kitchener, M. (2015). Value co-creation through patient engagement in health care: a micro-level approach and research agenda. Public Management Review, 17(1), 90-107.

Helkkula, A., Kelleher, C., \& Pihlström, M. (2012). Characterizing value as an experience: implications for service researchers and managers. Journal of Service Research, 15(1), 5975.

Hertel, G., Konradt, U., \& Orlikowski, B. (2004). Managing distance by interdependence: Goal setting, task interdependence, and team-based rewards in virtual teams. European Journal of work and organizational psychology, 13(1), 1-28.

Hsiao, C., Lee, Y.-H., \& Chen, W.-J. (2015). The effect of servant leadership on customer value co-creation: A cross-level analysis of key mediating roles. Tourism Management, 49, 4557.

Jaakkola, E., \& Alexander, M. (2014). The role of customer engagement behavior in value cocreation a service system perspective. Journal of Service Research, 17(3), 247-261. 
Kanfer, R. (1990). Motivation theory and industrial and organizational psychology. In M. D. Dunenette \& L. M. Hough (Eds.), Handbook of industrial and organizational psychology (Vol. 1, pp. 75-170). California: Consulting Psychologists Press.

Katz, D. (1964). The motivational basis of organizational behavior. Behavioral science, 9(2), 131146.

Kleinaltenkamp, M., Brodie, R. J., Frow, P., Hughes, T., Peters, L. D., \& Woratschek, H. (2012). Resource integration. Marketing Theory, 12(2), 201-205.

Kleinaltenkamp, M., Plewa, C., Gudergan, S., Karpen, I. O., \& Chen, T. (2017). Usage centervalue cocreation in multi-actor usage processes. Journal of Service Theory and Practice, 27(4), 721-737. doi:https://doi.org/10.1108/JSTP-04-2016-0074

Kruger, C., Caiado, R. G. G., França, S. L. B., \& Quelhas, O. L. G. (2018). A holistic model integrating value co-creation methodologies towards the sustainable development. Journal of Cleaner Production, 191, 400-416.

Kvale, S. (1995). The social construction of validity. Qualitative inquiry, 1(1), 19-40.

Latham, G. P., \& Pinder, C. C. (2005). Work motivation theory and research at the dawn of the twenty-first century. Annual review of psychology, 56, 485-516.

Lindenberg, S., \& Foss, N. J. (2011). Managing joint production motivation: The role of goal framing and governance mechanisms. Academy of management Review, 36(3), 500-525.

Locke, E. A., \& Latham, G. P. (2004). What should we do about motivation theory? Six recommendations for the twenty-first century. Academy of management Review, 29(3), $388-403$. 
MacKenzie, S. B., Podsakoff, P. M., \& Fetter, R. (1991). Organizational citizenship behavior and objective productivity as determinants of managerial evaluations of salespersons' performance. Organizational behavior and human decision processes, 50(1), 123-150.

Malthouse, E. C., \& Calder, B. J. (2011). Comment: engagement and experiences: comment on Brodie, Hollenbeek, Juric, and Ilic (2011). Journal of Service Research, 14(3), 277-279.

Merrilees, B., Miller, D., \& Yakimova, R. (2017). The role of staff engagement in facilitating staffled value co-creation. Journal of Service Management, 28(2), 250-264.

Mertens, D. M. (2015). Research and evaluation in education and psychology: Integrating diversity with quantitative, qualitative, and mixed methods (4 ed.). Thousand Oaks, CA: Sage Publications.

Mitchell, T. R. (1982). Motivation: New directions for theory, research, and practice. Academy of management Review, 7(1), 80-88.

Morey, N. C., \& Luthans, F. (1984). An emic perspective and ethnoscience methods for organizational research. Academy of management Review, 9(1), 27-36.

O'Cass, A., \& Sok, P. (2013). Exploring innovation driven value creation in B2B service firms: The roles of the manager, employees, and customers in value creation. Journal of Business Research, 66(8), 1074-1084.

Patrício, L., Gustafsson, A., \& Fisk, R. (2018). Upframing service design and innovation for research impact. Journal of Service Research, 21(1), 3-16.

Pinder, C. C. (1998). Work motivation in organizational behavior. Upper Saddle River, NJ: Prentice-Hall.

Plé, L. (2016). Studying customers' resource integration by service employees in interactional value co-creation. Journal of Services Marketing, 30(2), 152-164. 
Podsakoff, N. P., Whiting, S. W., Podsakoff, P. M., \& Blume, B. D. (2009). Individual-and organizational-level consequences of organizational citizenship behaviors: A metaanalysis. Journal of Applied Psychology, 94(1), 122-141.

Ramaswamy, V. (2009). Leading the transformation to co-creation of value. Strategy \& Leadership, 37(2), 32-37.

Randall, R., Ramaswamy, V., \& Chopra, N. (2014). Building a culture of co-creation at Mahindra. Strategy \& Leadership, 42(2), 12-18. doi:10.1108/s1-01-2014-0005

Roberts, D., Hughes, M., \& Kertbo, K. (2014). Exploring consumers' motivations to engage in innovation through co-creation activities. European Journal of Marketing, 48(1-2), 147169.

Sandberg, J. (2000). Understanding human competence at work: an interpretative approach. Academy of management journal, 43(1), 9-25.

Sandberg, J. (2005). How do we justify knowledge produced within interpretive approaches? Organizational Research Methods, 8(1), 41-68.

Santos-Vijande, M. L., López-Sánchez, J. Á., \& Rudd, J. (2016). Frontline employees' collaboration in industrial service innovation: routes of co-creation's effects on new service performance. Journal of the Academy of Marketing Science, 44(3), 350-375.

Saunders, M., Lewis, P., \& Thornhill, A. (2009). Research methods for business students (5 Ed.). Lombardy, Italy: Pearson Education.

Sluss, D. M., \& Ashforth, B. E. (2007). Relational identity and identification: Defining ourselves through work relationships. Academy of management Review, 32(1), 9-32.

Sonnentag, S., Volmer, J., \& Spychala, A. (2008). Job performance. The Sage handbook of organizational behavior, 1, 427-447. 
Storbacka, K., Brodie, R. J., Böhmann, T., Maglio, P. P., \& Nenonen, S. (2016). Actor engagement as a microfoundation for value co-creation. Journal of Business Research, 69(8), 30083017.

Taylor, S. J., \& Bogdan, R. (1984). Introduction to qualitative research methods: The search for meaning (2 ed.). New York: Wiley.

Van der Heijden, G. A., Schepers, J. J., Nijssen, E. J., \& Ordanini, A. (2013). Don't just fix it, make it better! Using frontline service employees to improve recovery performance. Journal of the Academy of Marketing Science, 41(5), 515-530.

Van Doorn, J., Lemon, K. N., Mittal, V., Nass, S., Pick, D., Pirner, P., \& Verhoef, P. C. (2010). Customer engagement behavior: Theoretical foundations and research directions. Journal of Service Research, 13(3), 253-266.

Vargo, S. L., \& Lusch, R. F. (2016). Institutions and axioms: an extension and update of servicedominant logic. Journal of the Academy of Marketing Science, 44(1), 5-23.

Vargo, S. L., \& Lusch, R. F. (2017). Service-dominant logic 2025. International Journal of Research in Marketing, 34(1), 46-67.

Vargo, S. L., Lusch, R. F., \& Akaka, M. A. (2010). Advancing Service Science with ServiceDominant Logic: Clarifications and Conceptual Development. In P. P. Maglio, C. A. Kieliszewski, \& J. C. Spohrer (Eds.), Handbook of Service Science (pp. 133-156). New York: Springer.

Waseem, D., Biggemann, S., \& Garry, T. (2018). Value co-creation: The role of actor competence. Industrial Marketing Management, 70, 5-12. doi:10.1016/j.indmarman.2017.07.005

Zhao, J., Wang, T., \& Fan, X. (2015). Patient value co-creation in online health communities. Journal of Service Management, 26(1), 72-96. 


\section{Figure 1}

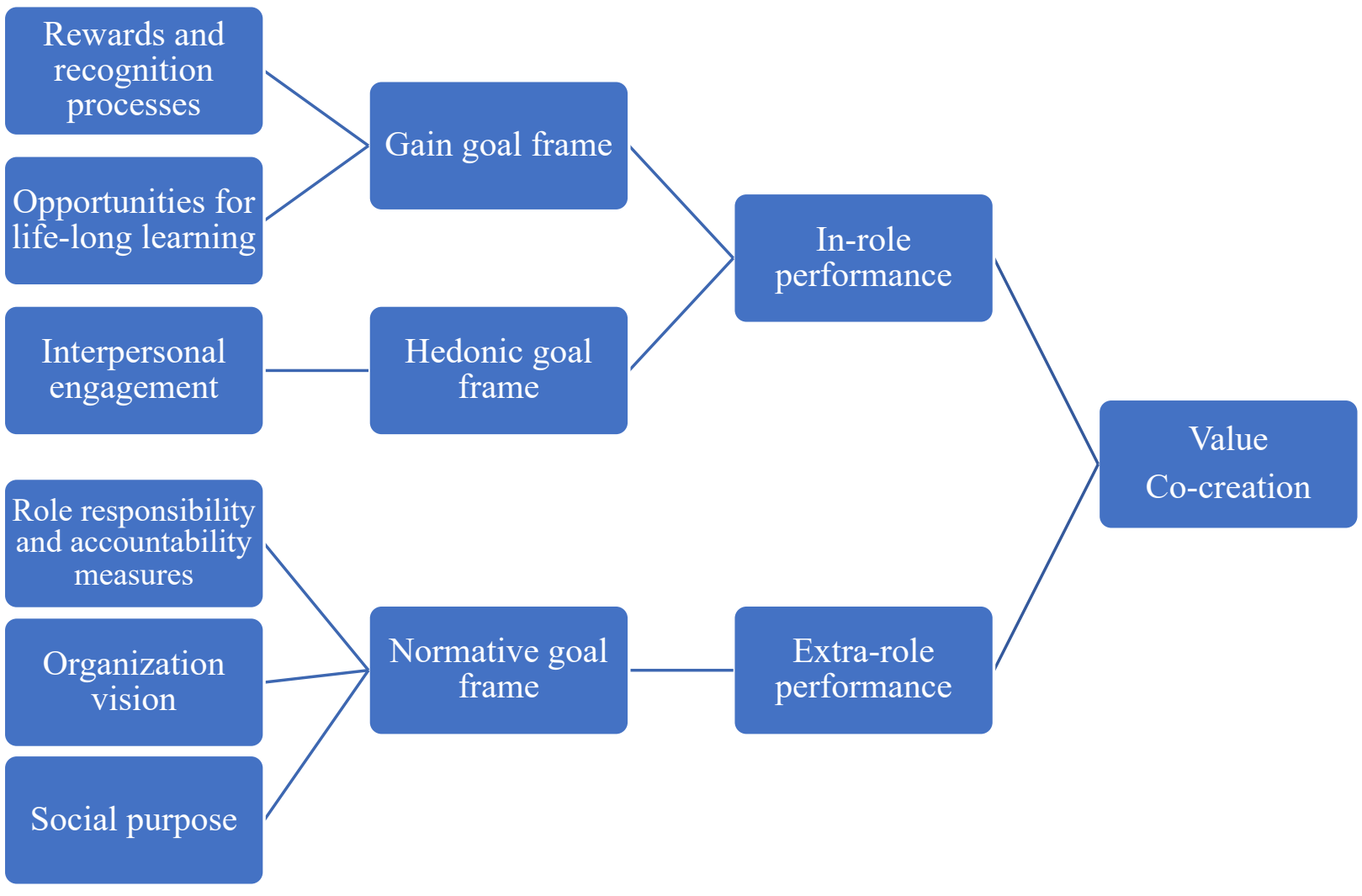

Figure 1: Categories of drivers of employee motivation that lead to in-role and extra-role performance that facilitate value co-creation 
Table I: Number of participants (P) and their details (age, function, management level)

\begin{tabular}{|c|c|c|c|c|}
\hline S. & Level & Department & Designation & Gender \\
\hline 1 & Corporate Level Executive & General Management & Vice Chairman - VC & Male \\
\hline 2 & Corporate Level Executive & General Management & $\begin{array}{l}\text { Chief Executive Officer - } \\
\text { CEO }\end{array}$ & Male \\
\hline 3 & Corporate Level Executive & General Management & $\begin{array}{l}\text { Chief Operation Officer - } \\
\mathrm{COO}\end{array}$ & Male \\
\hline 4 & Senior Management Executive & Sales and Marketing & $\begin{array}{l}\text { Sales \& Marketing - General } \\
\text { Manager }\end{array}$ & Male \\
\hline 5 & Senior Management Executive & Production & $\begin{array}{l}\text { Production - General } \\
\text { Manager }\end{array}$ & Male \\
\hline 6 & Senior Management Executive & Finance \& Audit & $\begin{array}{l}\text { Chief Financial Officer } \\
\text { (CFO) \& Finance Head }\end{array}$ & Male \\
\hline 7 & Middle Management Executive & Sales and Marketing & Business Unit Manager & Male \\
\hline 8 & Middle Management Executive & Sales and Marketing & Export Manager & Male \\
\hline 9 & Middle Management Executive & Sales and Marketing & Regional Sales Manager & Male \\
\hline 10 & Middle Management Executive & Sales and Marketing & $\begin{array}{l}\text { Product \& Marketing } \\
\text { Manager }\end{array}$ & Male \\
\hline 11 & Middle Management Executive & Sales and Marketing & Outlets Head - All Zones & Female \\
\hline 12 & Middle Management Executive & Production & $\begin{array}{l}\text { Lab - Assistant General } \\
\text { Manager }\end{array}$ & Male \\
\hline 13 & Middle Management Executive & Production & Manager (Unit 1) & Male \\
\hline 14 & Middle Management Executive & Production & Manager (Unit 2) & Male \\
\hline 15 & Middle Management Executive & Production & Manager (Unit 3) & Male \\
\hline
\end{tabular}




\begin{tabular}{|c|c|c|c|c|}
\hline 16 & Middle Management Executive & Finance \& Audit & Manager Finance & Male \\
\hline 17 & Middle Management Executive & Finance \& Audit & Manager Accounts & Male \\
\hline 18 & Middle Management Executive & Finance \& Audit & Head Audit & Male \\
\hline 19 & Middle Management Executive & $\begin{array}{l}\text { Quality } \\
\text { Assurance/Control }\end{array}$ & Quality Assurance Head & Male \\
\hline 20 & Middle Management Executive & Human Resources & HR Manager & Male \\
\hline 21 & Middle Management Executive & $\begin{array}{l}\text { Information } \\
\text { Technology }\end{array}$ & Manager IT & Male \\
\hline 22 & Middle Management Executive & $\begin{array}{l}\text { Supply Chain } \\
\text { Management }\end{array}$ & Supply Chain Head & Male \\
\hline 23 & Middle Management Executive & Sales and Marketing & Manager Sales & Male \\
\hline 24 & Middle Management Executive & Sales and Marketing & Area Manager & Male \\
\hline 25 & Middle Management Executive & Sales and Marketing & Product Manager & Male \\
\hline 26 & Middle Management Executive & Sales and Marketing & Manager Outlets & Male \\
\hline 27 & Middle Management Executive & Sales and Marketing & $\begin{array}{l}\text { Product development - } \\
\text { Manager }\end{array}$ & Male \\
\hline 28 & Middle Management Executive & Production & Sorting Manager & Male \\
\hline 29 & Middle Management Executive & Production & Product Planning Manager & Male \\
\hline 30 & Middle Management Executive & Production & Press Manager & Male \\
\hline 31 & Middle Management Executive & Finance \& Audit & Financial Reporting - SO & Male \\
\hline 32 & Middle Management Executive & Finance \& Audit & Account Receivable - DM & Male \\
\hline 33 & Middle Management Executive & Finance \& Audit & Manager Internal Audit & Male \\
\hline 34 & Middle Management Executive & $\begin{array}{l}\text { Quality } \\
\text { Assurance/Control }\end{array}$ & Manager Quality Control & Male \\
\hline 35 & Middle Management Executive & Human Resources & Recruitment - DM & Female \\
\hline
\end{tabular}




\begin{tabular}{|c|c|c|c|c|}
\hline 36 & Middle Management Executive & Human Resources & $\begin{array}{l}\text { Compensation and Benefits - } \\
\text { DM }\end{array}$ & Male \\
\hline 37 & Middle Management Executive & $\begin{array}{l}\text { Information } \\
\text { Technology }\end{array}$ & $\begin{array}{l}\text { Techno Functional } \\
\text { Consultant }\end{array}$ & Male \\
\hline 38 & Middle Management Executive & $\begin{array}{l}\text { Information } \\
\text { Technology }\end{array}$ & Techno Consultant & Male \\
\hline 39 & Middle Management Executive & Production & Manager Finished Goods & Male \\
\hline 40 & Middle Management Executive & $\begin{array}{l}\text { Supply Chain } \\
\text { Management }\end{array}$ & Manager Imports & Male \\
\hline 41 & Middle Management Executive & $\begin{array}{l}\text { Supply Chain } \\
\text { Management }\end{array}$ & Manager Purchase & Male \\
\hline 42 & $\begin{array}{l}\text { Lower-Level Management } \\
\text { Executive }\end{array}$ & Sales and Marketing & Territory Sales Manager & Male \\
\hline 43 & $\begin{array}{l}\text { Lower-Level Management } \\
\text { Executive }\end{array}$ & Sales and Marketing & Product - DM & Female \\
\hline 44 & $\begin{array}{l}\text { Lower-Level Management } \\
\text { Executive }\end{array}$ & Production & Production Planning - AM & Male \\
\hline 45 & $\begin{array}{l}\text { Lower-Level Management } \\
\text { Executive }\end{array}$ & Finance \& Audit & Audit - Sr. Officer & Male \\
\hline 46 & $\begin{array}{l}\text { Lower-Level Management } \\
\text { Executive }\end{array}$ & Finance \& Audit & Internal Audit - AM 1 & Male \\
\hline 47 & $\begin{array}{l}\text { Lower-Level Management } \\
\text { Executive }\end{array}$ & $\begin{array}{l}\text { Quality } \\
\text { Assurance/Control }\end{array}$ & QC - Officer 1 & Male \\
\hline 48 & $\begin{array}{l}\text { Lower-Level Management } \\
\text { Executive }\end{array}$ & Human Resources & Recruitment - AM & Male \\
\hline
\end{tabular}




\begin{tabular}{|c|c|c|c|c|}
\hline 49 & $\begin{array}{l}\text { Lower-Level Management } \\
\text { Executive }\end{array}$ & Human Resources & $\begin{array}{l}\text { Compensation and Benefits - } \\
\text { AM }\end{array}$ & Female \\
\hline 50 & $\begin{array}{l}\text { Lower-Level Management } \\
\text { Executive }\end{array}$ & $\begin{array}{l}\text { Information } \\
\text { Technology }\end{array}$ & IT - AM & Male \\
\hline 51 & $\begin{array}{l}\text { Lower-Level Management } \\
\text { Executive }\end{array}$ & $\begin{array}{l}\text { Information } \\
\text { Technology }\end{array}$ & IT Officer & Male \\
\hline 52 & $\begin{array}{l}\text { Lower-Level Management } \\
\text { Executive }\end{array}$ & Sales and Marketing & Sales Officer (SPO) & Male \\
\hline 53 & $\begin{array}{l}\text { Lower-Level Management } \\
\text { Executive }\end{array}$ & Production & Design - AM & Female \\
\hline 54 & $\begin{array}{l}\text { Lower-Level Management } \\
\text { Executive }\end{array}$ & $\begin{array}{l}\text { Supply Chain } \\
\text { Management }\end{array}$ & $\begin{array}{l}\text { Material Resource Planning - } \\
\text { AM }\end{array}$ & Male \\
\hline 55 & $\begin{array}{l}\text { Lower-Level Management } \\
\text { Executive }\end{array}$ & Finance \& Audit & Internal Audit - AM 2 & Male \\
\hline 56 & $\begin{array}{l}\text { Lower-Level Management } \\
\text { Executive }\end{array}$ & $\begin{array}{l}\text { Quality } \\
\text { Assurance/Control }\end{array}$ & QC - Officer 2 & Male \\
\hline 57 & $\begin{array}{l}\text { Lower-Level Management } \\
\text { Executive }\end{array}$ & Sales and Marketing & Marketing - AM & Male \\
\hline
\end{tabular}

\begin{tabular}{|l}
\hline $\mathrm{DM}=$ Deputy Manager \\
\hline $\mathrm{AM}=$ Assistant Manager \\
\hline $\mathrm{SO}=$ Senior Officer
\end{tabular}


Table II: Key drivers of employee motivation that facilitate value co-creation

\begin{tabular}{|l|c|c|}
\hline \multicolumn{1}{|c|}{ First-order codes } & Second-order theme & Third-order themes \\
\hline Systematic succession planning & Recognition & Reward and \\
\cline { 1 - 1 } Boosting employee morale & & recognition processes \\
\cline { 1 - 1 } Incentive systems and processes & Rewards & \\
\hline Monetary benefits and facilities & & \\
\hline
\end{tabular}

\begin{tabular}{|c|c|c|}
\hline Knowledge sharing with others & \multirow{5}{*}{$\begin{array}{c}\text { Personal development } \\
\text { opportunities }\end{array}$} & \multirow{7}{*}{$\begin{array}{l}\text { Opportunities for life- } \\
\text { long learning }\end{array}$} \\
\hline Career development planning & & \\
\hline Training of employees & & \\
\hline Counsel employees & & \\
\hline $\begin{array}{l}\text { Empowerment and decision } \\
\text { making }\end{array}$ & & \\
\hline $\begin{array}{l}\text { Participative environments } \\
\text { encompassing all employees }\end{array}$ & \multirow{2}{*}{$\begin{array}{c}\text { Collective development } \\
\text { opportunities }\end{array}$} & \\
\hline $\begin{array}{l}\text { Facilitation of team building } \\
\text { Team support }\end{array}$ & & \\
\hline
\end{tabular}

\begin{tabular}{|l|l|l|}
\hline No communication gaps & & Interpersonal \\
\cline { 1 - 1 } Ensuring direct interaction & Interactions Characteristics & Engagements \\
\hline Equal treatment of all employees & & \\
\hline
\end{tabular}




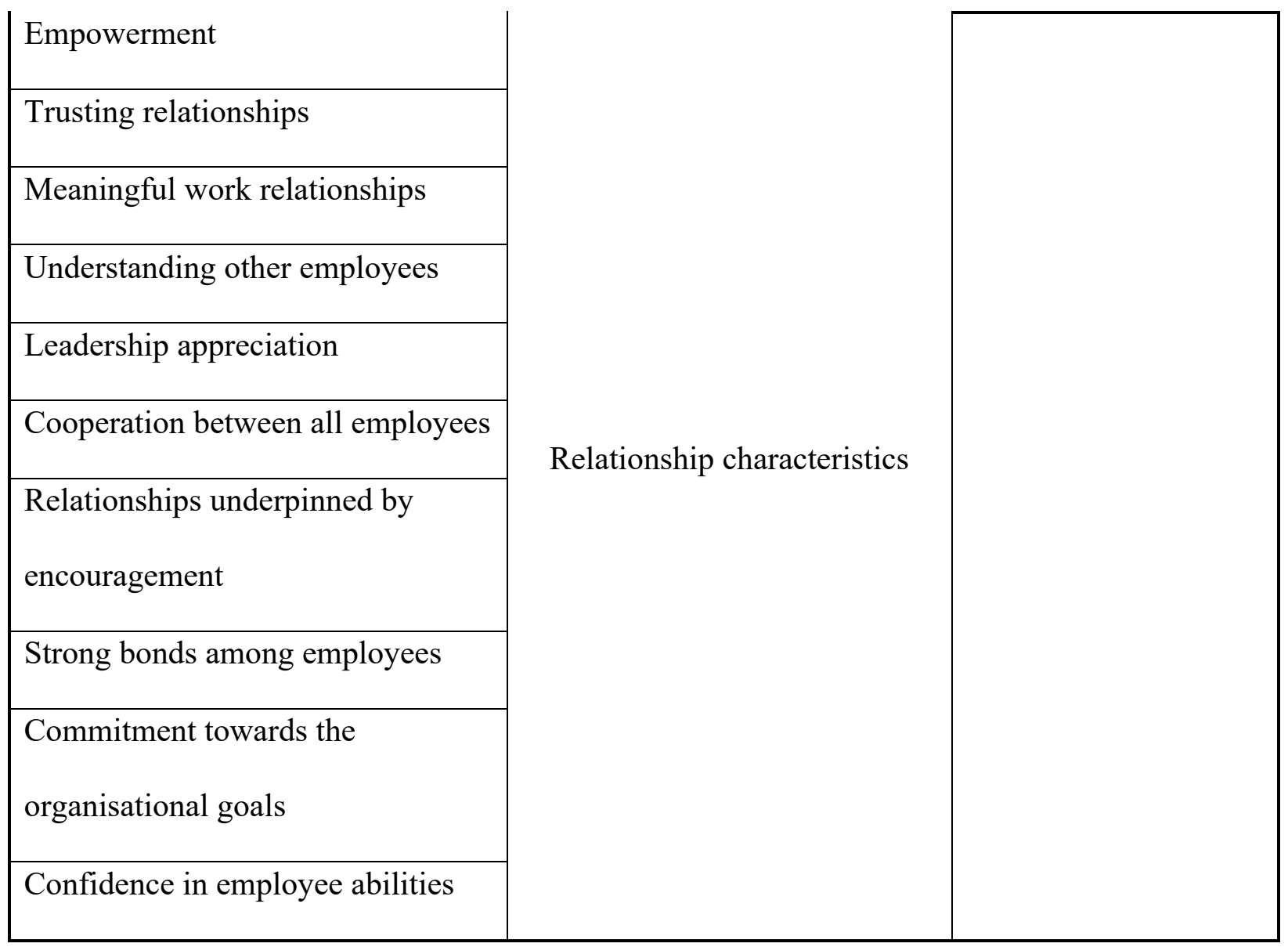

\begin{tabular}{|c|c|c|}
\hline Make people accountable & \multirow{4}{*}{ Accountability } & \multirow{7}{*}{$\begin{array}{l}\text { Role responsibility } \\
\text { and accountability } \\
\text { measures }\end{array}$} \\
\hline Setting high standards & & \\
\hline Results-driven accountability & & \\
\hline Transparency in all processes & & \\
\hline Role clarity to perform the job & \multirow{3}{*}{ Role responsibility } & \\
\hline Specific job descriptions & & \\
\hline $\begin{array}{l}\text { Directly ask the responsible } \\
\text { employee }\end{array}$ & & \\
\hline Caring organization & Characteristics & Organizational vision \\
\hline
\end{tabular}




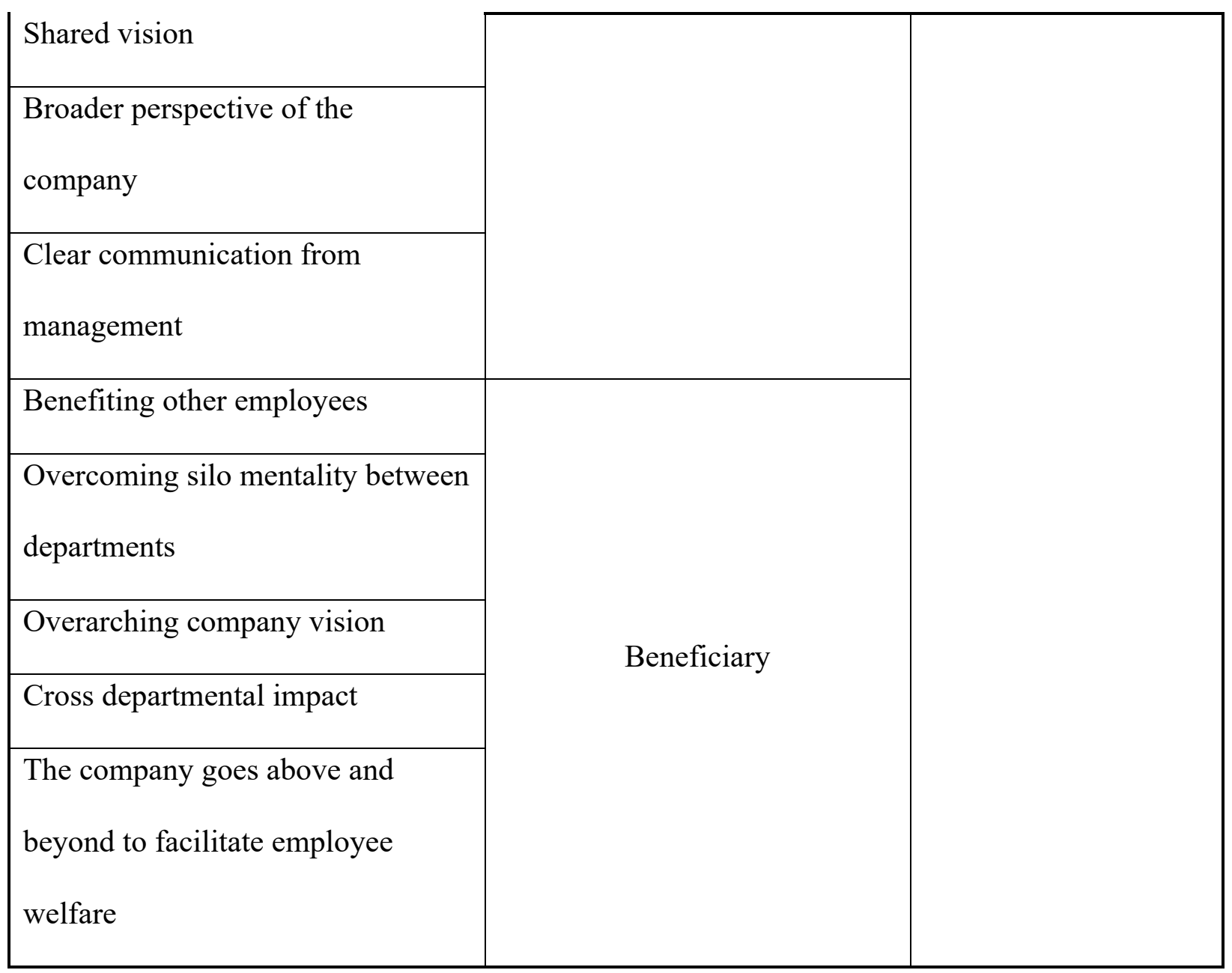

\begin{tabular}{|c|c|c|}
\hline Collective goals to benefit society & \multirow{4}{*}{ Characteristics } & \multirow{5}{*}{ Social purpose } \\
\hline $\begin{array}{l}\text { The company goes above and } \\
\text { beyond to facilitate societal welfare }\end{array}$ & & \\
\hline $\begin{array}{l}\text { Company relationship with } \\
\text { employees' families }\end{array}$ & & \\
\hline $\begin{array}{l}\text { Communication strategy based on } \\
\text { the greater good }\end{array}$ & & \\
\hline $\begin{array}{l}\text { Contribution towards firm or } \\
\text { society }\end{array}$ & Beneficiary & \\
\hline
\end{tabular}




\begin{tabular}{|l|} 
Impact beyond the company \\
\hline Consider the impact on the \\
environment
\end{tabular}

